Etnográfica

Revista do Centro em Rede de Investigação em

Antropologia

vol. $18(2) \mid 2014$

Vol. $18(2)$

\title{
Anthropologists behaving badly? Impact and the politics of evaluation in an era of accountability
}

Antropólogos com mau comportamento? 0 impacto e as políticas da avaliação numa época de prestação de contas

Jon P. Mitchell

\section{(2) OpenEdition}

Journals

Electronic version

URL: https://journals.openedition.org/etnografica/3673

DOI: 10.4000/etnografica.3673

ISSN: 2182-2891

\section{Publisher}

Centro em Rede de Investigação em Antropologia

\section{Printed version}

Date of publication: 1 June 2014

Number of pages: $275-297$

ISSN: 0873-6561

\section{Electronic reference}

Jon P. Mitchell, "Anthropologists behaving badly? Impact and the politics of evaluation in an era of accountability", Etnográfica [Online], vol. 18 (2) | 2014, Online since 09 July 2014, connection on 10 February 2022. URL: http://journals.openedition.org/etnografica/3673 ; DOI: https://doi.org/10.4000/ etnografica.3673

\section{(c) (;) (9)}

Etnográfica is licensed under a Creative Commons Attribution-NonCommercial 4.0 International License. 


\section{Anthropologists behaving badly? Impact and the politics of evaluation in an era of accountability}

\section{Jon P. Mitchell}

This paper discusses the move within UK social science funding to use non-academic 'impact' as a measure of quality and success for social research. It suggests that behind this move are a set of unspoken assumptions about what constitutes 'good' and 'bad' impact, and the paper seeks to problematize these. By way of provocation, it presents three classic cases of anthropological research, in which the impact of anthropologists on the societies in which they worked was at worst reprehensible, and at best controversial. These controversies - Darkness in El Dorado, the Human Terrain System and Fields of Wheat, Hills of Blood - are used to demonstrate the difficulty with which we can assess impacts as 'good' or 'bad', and the problems with attempting to do so.

KEYWORDS: impact, accountability, audit, neoliberalism, Research Excellence Framework (REF), UK.

Antropólogos com mau comportamento? O impacto e as políticas da avaliação numa época de prestação de contas - $\mathrm{O}$ artigo analisa como o financiamento das ciências sociais no Reino Unido passou a usar o "impacto" não académico como indicador da qualidade e do êxito da investigação social. O autor sugere que por detrás desta mudança está um conjunto de pressupostos silenciados sobre o que constitui o "bom" e o "mau" impacto, procurando problematizá-los. De modo provocatório, são apresentados três casos clássicos e controversos na antropologia, nos quais o impacto dos antropólogos sobre as sociedades em que trabalharam foi, na pior das hipóteses, repreensível, e na melhor, discutível. Estes casos - as controvérsias em torno de Darkness in El Dorado, o Human Terrain System e Fields of Wheat, Hills of Blood - são usados para demonstrar a dificuldade de avaliar o impacto como "bom" ou "mau" e os problemas enfrentados quando se tenta fazê-lo.

PALAVRAS-CHAVE: impacto, quantificação, auditoria, neoliberalismo, avaliação do ensino superior, Reino Unido.

MITCHELL, Jon P. (j.p.mitchell@sussex.ac.uk) - Department of Anthropology, University of Sussex, UK. 


\section{AUSTERITY, ACCOUNTABILITY, IMPACT}

"What is put in the hands of this bureaucratic leviathan is nothing less than the power to replace and reshape the criteria of validity governing anthropological knowledge in Britain" (Barth 2002: 9).

After coming to power in May 2010, the UK's Conservative/Liberal Democrat coalition government announced a root and branch review of public sector spending, with the express aim of cutting the national budget deficit. This review - dubbed the Comprehensive Spending Review - planned an average 19\% reduction in government departmental budgets, although key budgets in health, international development, and schools, were exempt. Also ringfenced was the UK's science budget - government funding for research across natural and social sciences, and the humanities. The science budget is administered by Research Councils UK (RCUK), a politically independent but publicly accountable consortium that includes the Economic and Social Research Council (ESRC) that is responsible for funding research in the social sciences, including anthropology. ${ }^{1}$

The financial protection for research was welcomed by RCUK and across the UK research community, but at presentations from RCUK officials to research leaders in Universities and research institutes, it became clear that this protection came at a price. The price was accountability, demonstrating 'value for money' but particularly establishing the links between funded research and wider effects - or impacts - outside the academic sphere. For RCUK, impact is by definition non-academic, or extra-academic, defining it as "the demonstrable contribution that excellent research makes to society and the economy". ${ }^{2}$ It is framed in terms of benefits: to economic performance, and the UK's competitiveness; to the effectiveness of public service and policy; to quality of life, health and creativity. To the clearer-minded RCUK bureaucrats, this was about providing the ministers in charge of science funding with clear and unambiguous evidence that research has impact in the wider world. Prioritising impact, RCUK changed its motto and website banner - to 'Excellence with Impact' and developed new tools with which prospective researchers were to 'plan for impact'. In the social sciences - among them anthropology - researchers are now to plan for economic and social impact. Scholars applying to the Economic and Social Research Council (ESRC - the member of RCUK that oversees social science funding) are required to develop a 'pathways to impact'

$1 \quad$ See <http://www.publicfinance.co.uk/features/2013/05/the-state-of-things-to-come/ > (last access 2014, May).

2 See <http://www.esrc.ac.uk/funding-and-guidance/impact-toolkit/what-how-and-why/what-is-research-impact.aspx $>$ (last access 2014, May). 
statement that outlines their strategies for maximising potential impact. This might include public events, a website or weblog, policy briefing, publication of non-academic outputs (films, novels, comic strip etc.), liaison with governmental or non-governmental organisations etc. It becomes one of the criteria through which the quality of a research application is judged but also, perhaps more significantly, one of the criteria through which the success or failure of a project is later judged - did the project succeed in implementing its impact plan?

The other main source of state funding for research in the UK comes via the higher education funding councils, which provide direct grants to Universities. The Comprehensive Spending Review was even more radical with the higher education budget, which was cut by $40 \%$. Funding was withdrawn for undergraduate students in all but the so-called STEM subjects (science, technology, engineering and mathematics). Postgraduate students are funded only on a competitive basis, by the research councils. General research funding, not linked to specific research projects - so-called QR or 'quality-related' funding - was, like the Research Council money, increasingly tied to impact. Since 1986, the levels of QR funding have been governed by a periodic audit of research output and quality. An initial 'research selectivity exercise' was subsequently replaced by a 'research assessment exercise' (RAE) and latterly 'research excellence framework' (REF). The first REF will take place in 2014, to determine levels of $\mathrm{QR}$ funding to individual 'units of assessment' - mostly academic Departments - across the University sector. The REF is principally a measure of the academic quality of a Department's research outputs - by which is principally meant publications - but also of the quality of its research environment and strategy, the successful completion of PhD students, and - for the first time in the history of these audits - impact. Units of assessment are asked to submit a number of 'impact case studies' - the number dependent on the size of Department - that establish a link between published research and specific demonstrable impact in wider society. These are then judged according to the clarity and coherence of the narrative account of the case study, and the 'reach and significance' of the impact claimed for the research - its scale and importance.

This paper examines the consequences of this turn towards impact, particularly for research in anthropology. Whilst I do not wish to suggest that impact per se is a bad thing. Far from it. Much - perhaps most - anthropological research has a very positive contribution to make to the societies studied, and humanity as a whole. What concerns me is the extent to which too strong an emphasis on impact - particularly in the predictive or prospective sense required by the ESRC - threatens to instrumentalise the research process, with grants being awarded to research projects that offer the clearest and most watertight 'pathway to impact', rather than other types of project. It also 
leads to series of implicit - and often not so implicit - judgements about what kinds of impact are most desirable. The impact agenda appears to assume that impact is by definition a good thing - or at least that there is consensus about what 'good' and 'bad' impacts are. This is not the case, and disagreements about impact can revolve around ethical concerns, differences of intellectual perspective, or political differences.

This paper addresses the implications of impact for anthropological research, focusing particularly on these difficult issues of evaluation. In order to do so it examines three cases of anthropologists accused of 'bad' impact - the first incontrovertibly; the second arguably; the third according to political activists from the country in which the research took place. The first is James Neel and Napoleon Chagnon's research on the Yanomami, which sparked the Darkness in El Dorado controversy that accused them of exacerbating or even causing a measles epidemic, and exaggerating - and again exacerbating - intra-ethnic violence. Whilst Neel and Chagnon have been exonerated of the former charge, the latter remains a matter for debate, the terms of which depend in part on intellectual politics. The second case is the 'Human Terrain' programme of embedding anthropologists within the US military in Iraq and Afghanistan, which supporters claim reduces the need for kinetic/violent counterinsurgency, but concerned anthropologists saw as a co-option of anthropology to assist in identifying targets. Moreover, they argued, it threatened the safety of other anthropologists who might be falsely identified as linked to the military. The third is Anastasia Karakasidou's research in Greek Macedonia, which identified a Macedonian Slav minority, prompting threats of violence and the ultimate withdrawal of her book, Fields of Wheat, Hills of Blood (1997) from the Cambridge University Press anthropology list.

The paper will consider the implications of treating these three research projects as if they were the 'underpinning research' of impact case studies submitted for evaluation in the REF. It is intended as a provocation or critique, rather than an argument about how research should be evaluated. Rather, it points towards the difficult issues underlying what might appear to be the relatively simple process of accounting for impact in anthropological research.

Before we get there, however, the next section of the paper addresses the relationship between the idea of prospective planning for impact, inherent in the RCUK model of impact, and the retrospective focus of the REF. The notion of planned impact poses a particular problem for anthropological research, which is normally based on ethnographic fieldwork that is by definition volatile, unpredictable and difficult to plan. Impacts, like research foci and research data, arrive serendipitously (Okely 2012). Indeed, the REF acknowledges this, requiring only that the impact narrative demonstrates clear causal 'chains of evidence' linking research to impact, not that the impact was derived from a coherent plan. This may come in future REF, but at the moment it seems that 
the twin technologies of impact assessment and audit are pulling in two opposite directions. For the meantime, while RCUK encourages forward planning, REF encourages a backwards-looking narrative, or teleological historiography, that reads backwards from consequences (impact) to causes, and re-visions research as a process inevitably leading to impact.

\section{NEOLIBERALISM, NARRATIVE AND RESEARCH ENTREPRENEURIALISM}

Cris Shore locates academic audits such as the REF firmly within the apparatus of neoliberal governance. The focus on public and shareholder accountability creates a paradox, of an ideological position that is strongly libertarian which nevertheless brings with it powerful technologies of control. Overt deregulation is accompanied by covert disciplining, which is effectively devolved to individual actors who become the regulators of their own action. Nowhere is this more strongly demonstrated than within the discourses of professionalization and professionalism that have accompanied public policy since the 1980s. As Shore points out:

"A key characteristic of neoliberal governance is that it relies on more indirect forms of intervention and control. In particular, it seeks to act on and through the agency, interests, desires and motivations of individuals, encouraging them to see themselves as active subjects responsible for improving their own conduct" (Shore 2008: 284).

To be professional is to self-regulate. Moreover, in the context of research, being successful - getting grants, and having your work judged as high quality depends on your ability to demonstrate and perform this self-regulation in the periodic audits and reporting mechanisms required by the research infrastructure: the REF and RCUK impact planning. Success in the audit process requires a successful orientation to the temporalities of neoliberalism - an ability to finesse the requirements of their prospective and retrospective accounting.

Binkley has explored the relationship between neoliberalism, governance and temporality (Binkley 2009a, 2009b). He uses Robert T. Kiyosaki's popular business self-help book Rich Dad/Poor Dad (Kiyosaki 2002) as an illustration of the contrast neoliberal thinking makes between a disciplined, regimented and ultimately conservative mode of being (poor dad) and an entrepreneurial mode of being (rich dad). Whilst the former is characteristic of classical liberalism - an orientation to work, money and risk that emphasises the social contracts and mutual responsibilities of employer and employee - the latter characterises neoliberalism, with its emphasis on individual responsibility, autonomy and self-sufficiency. The purpose of the book is to encourage a move from 'poor dad' mentality to 'rich dad' - a move that requires radical 
self-transformation, but which will ultimately bring wealth and happiness. The different orientation of the two 'dads' to temporality is instructive:

"poor dads practice a docile compliance to the prescribed rhythms and schedules of the institutions within which their faith is invested and their trajectories marked [...] rich dads, or neoliberal agents, take this docility as the specific object of an ethical program, assuming full responsibility for the temporality of their own conduct, managing risks and projecting their futures against opportunistic horizons tailored to their own unique projects" (Binkley 2009a: 69).

The key to navigating the 'ethical program' of neoliberalism is a particular orientation to narrative as reflexive biography (Binkley 2009b: 93). Reflexive biography reconfigures narrative as simultaneously backwards- and forwards-looking, combining coherent retrospective with "projection into the future of a trajectory of expected outcomes and events" (Binkley 2009b: 93). It places the individual subject as this narrative's author, with a responsibility to conduct the passage from past through present to future:

“... the individual must therefore learn, on pain of permanent disadvantage, to conceive of himself or herself as the centre of action, as the planning office with respect to his/her own biography, abilities, orientations, relationship and so on" (Beck 1992: 135).

This is the temporal apogee of processes identified by Habermas as characteristic of modernity itself: the re-ordering of time as successive moments of present which sequentially unfold, hinging the relationship between past and future (Habermas 1987, see also Miller 1994). With the individual subject at the centre of this process - managing the hinge, as it were - there is a new personal responsibility to rein in the narrative and generate order, describing the present as the purposive outcome of a chain of events that has narrative integrity, and the future as a planned unfolding of that narrative.

If, as Shore suggests, neoliberal governance is the driving force behind contemporary audit regimes - the audit culture, or audit society (Power 1997, Strathern 2000) - it is also the driving force behind the audit of impact. One of the consequences of the move towards audit accountability and managerialism in research is, according to Ozga, a shift towards research entrepreneurialism: "transformation of the liberal intellectual researcher into the researcher as entrepreneur" (Ozga 1998: 147). This requires an entrepreneurial orientation not only to the business of applying for, securing and delivering on research grants, but also an entrepreneurial orientation to accountability and audit. Following Binkley's argument, this also requires an orientation to the narration 
of research in which researchers must now also describe themselves and their worlds in entrepreneurial terms. This means generating 'rich dad' narratives of entrepreneurial research success. My argument here is that the impact requirements of REF and RCUK not only encourage but specifically require this type of neoliberal narration, demanding a recasting of the past as not only leading to but intentionally designed to produce impact, and a vision of the future in which impact is the goal. In doing so it throws up some problematic paradoxes. As a results-driven exercise that focuses on impact as a quantity or end it risks ignoring or bypassing issues of the quality or value of impact: what kinds of impact are we talking about when we talk about impact? Is all impact 'good' impact, or are there certain types of impact that are more valued than others? Part of my argument is that the assessment of the quality of impact is bound to be contextual, and political, depending both on one's view of the purpose of social science, and on one's view of the world. Hence an evaluation of the impact of Napoleon Chagnon's work on the Yanomami would depend on the available and accepted evidence, as well as one's broader perspective on the place of US anthropology in the development of indigenous rights and society. An evaluation of the Human Terrain impact would depend on one's view of the place of anthropology within the military, and an evaluation of Karakasidou's research would depend on one's stance on the Macedonian question.

\section{ASSESSING IMPACT}

UK research assessment audit began in 1986. The 2014 REF will be the seventh such audit, aimed at establishing grounds for a targeted distribution - or redistribution - of QR research funding. Units of assessment - usually academic Departments - are required to submit evidence that is used to generate an overall grading of research quality, and from that a league table of departments and institutions. Various different methodologies have been used to translate these gradings into the distribution of funds, but with budgets increasingly tight across successive research assessment audits, the pressure has increased to score highly.

Preparations for the REF, as RAE before it, have involved a certain amount of intrigue and 'dirty tricks' on the part of strategising Universities and units of assessment. These range from star hiring, through the issuing of fractional contracts to emeritus faculty who an institution wishes to 'claim', to excluding certain scholars who it is felt are not 'up to scratch' in their research output. As Shore points out, this can have potentially devastating effects on an individual's career, effectively declaring them not 'research active' and therefore in breach of contract (Shore 2008: 285).

Although the ultimate judgements about quality are made at a national level, with unit of assessment scores aggregated at institutional and departmental 
levels, the responsibility for delivering quality output is devolved to individual researchers. As Binkley has argued:

"Neoliberal governmentality presumes a more or less continuous series that runs from those macro-technologies by which states govern populations, to the micro-technologies by which individuals govern themselves" (Binkley 2009a: 62).

Each individual faculty member submitted to REF is required to submit a certain number of publications - usually four - that are then judged according to their quality and academic impact. The judging panels are expert peer reviewers, and in the case of anthropology at least, have resisted an over-reliance on metrics or citation indices, as well as too rigid a classification of journal impact. However, pressure from academic school and faculty managers - who are often from disciplines that are more prescriptive in this respect can itself have an impact on the research that is submitted, therefore research that is conducted. As well as individual research output quality, departments have been required to submit a statement of research strategy, research environment - including the numbers of successfully-defended PhD in the department - research funding secured, and reputational or esteem measures such as book prizes, invitations to deliver keynote speeches, international committee memberships etc.

For the first time, the 2014 REF will also assess impact beyond this academic frame:

"That is, the impact of the research of a submitting unit beyond any impact on or contribution to research or the advancement of knowledge within the higher education sector, and beyond impact on students, teaching or other activities within the submitting HEI [Higher Education Institution]" (NCCPE 2011:27).

Impact is defined as:

"An effect on, change or benefit to the economy, society, culture, public policy or services, health, the environment or quality of life, beyond academia [...] Impact includes, but is not limited to, an effect on, change or benefit to:

- the activity, attitude, awareness, behaviour, capacity, opportunity, performance, policy, practice, process or understanding

- of an audience, beneficiary, community, constituency, organisation or individuals

- in any geographic location whether locally, regionally, nationally or internationally. 
Impact includes the reduction or prevention of harm, risk, cost or other negative effects" (REF 2011: 58).

In the 2014 REF, units of assessment will submit their evidence to one of four interdisciplinary panels dealing respectively with: biological sciences; natural sciences; social sciences; humanities. Each main panel then has within it a number of disciplinary or cross-disciplinary sub-panels. Anthropology is placed alongside the other social sciences, in a joint sub-panel with Development Studies. The social science 'main panel' - panel C - has a broad understanding of what impact might constitute:

“... impact within its remit may take many forms and occur in a wide range of spheres. These may include (but are not restricted to): creativity, culture and society; the economy, commerce or organisations; the environment; health and welfare; practitioners and professional services; public policy, law and services. The categories used to define spheres of impact, for the purpose of this document, inevitably overlap and should not be taken as restrictive. Case studies may describe impacts which have affected more than one sphere" (REF 2012: 68).

Each unit of assessment is required to submit one impact case study, plus one more for every 10 eligible researchers within the unit. Case studies are a maximum of 4 pages long, and are geared towards establishing a clear narrative or 'chain of evidence' linking impact back to the 'underpinning research' that led to impact. The underpinning research must have taken place between 1993 and 2013, and itself judged to be of high quality. The impact must have taken place between 2008 and 2013 - the period of the REF review period. REF panel C acknowledges that the "relationship between research and impact may be neither direct nor linear" (REF 2012: 68), but the emphasis on generating a narrative account that presents a chain of evidence suggests an onus on the unit of assessment - or individual researchers - to create an account that links them together. Moreover, the quality of the narrative itself is one of the criteria by which impact case studies are evaluated:

"The sub-panels will use their expert judgement regarding the integrity, coherence and clarity of the narrative of each case study, but will expect that the key claims made in the narrative to be [sic] supported by evidence and indicators" (REF 2012: 71).

With impact described as an 'effect, change or benefit' to society or economy, there is no definitive statement that an impact has to be 'good'. Soon after the REF impact guidelines were launched, I attended a faculty-level meeting at 
my home University, and asked whether an impact considered negative - 'bad' impact - might score highly in the assessment, if based on high quality research and clearly narrated with a watertight chain of evidence. The suggestion was greeted with a mildly amused incredulity. In a context in which impact case studies are self-nominated, why would anybody wish to draw attention to a negative impact? Yet the question was not simply mischievous. I had in mind the case of Neel and Chagnon, who were accused of doing substantive damage to the Yanomami, but also less clear-cut examples of impact, particularly that which might be seen to go against the political or economic interests of established nation-states - and in this case, what has been described as UK PLC. ${ }^{3}$

For example, if it could be shown that anthropological knowledge had contributed to the theory and practice of contemporary counter-capitalist protest/revolt, could this be counted as successful impact? David Graeber's piece Revolution in Reverse predicts the demise of global capital, then makes an attempt to "contribute to a broader project re-imagining" (2007: 28) alternative configurations, based on the experiences and practices of direct action. The piece was picked up by and posted on theanarchistlibrary.org, ensuring a wide readership among the global movements associated with 'alterglobalisation' and the 'occupy' movements. Both sets of movements are deeply concerned with alternative models of democracy (Maeckelbergh 2009, 2012), but also with configuring the relationship between activism and intellectualism - practice and theory. Himself working within this duality - and indeed within the movements - Graeber might claim impact within and upon them; contributing to new ways of 're-imagining' and practicing protest. Needless to say, this would be seen as 'bad' impact by state apparatuses geared towards the maintenance of 'law and order' and the established economic order. But if it could be shown to make protest more effective, might it be seen as 'impact'?

My point is that decisions about 'good' and 'bad' impact will always depend on a context; of prevailing ideas about what constitutes benefit, progress and so forth. This raises problems for research that occupies the more critical ends of the social sciences - for whom received wisdom about 'good' impacts might be problematic - but particularly so for anthropology. The discipline's cross-cultural remit almost guarantees that there are at least differences - and often substantial conflict - over definitions of progress, and therefore also of 'beneficial' impact. These depend in turn on differing political viewpoints within either established politics or academic politics.

There are plenty of examples of anthropologists doing 'good' impact. Indeed, when the need for impact case studies was announced, my Department began

3 PLC stands for Public Limited Company, the UK legal designation for large business whose shares are publicly traded. The phrase UK PLC draws attention to the increased financialisation of the nationstate in an era of neoliberalism. 
collating examples in which anthropologists had had impact through engagements with development, migration, human rights. However, to bring into relief the processes of evaluation inherent in judging 'good' and 'bad' impact, I will focus on three examples of anthropologists doing 'bad' impact - or at least 'bad' in the eyes of an important evaluative constituency.

\section{DARKNESS IN EL DORADO}

In 2000 the journalist Patrick Tierney published Darkness in El Dorado, an account of the impact of anthropologists and geneticists on people of the Yanomami indigenous group in the Amazonian forest. It focused on the impact of anthropologist Napoleon Chagnon and his geneticist colleague James Neel, who have worked with the Yanomami since the 1960s. The book makes various claims against both Chagnon and Neel, and indeed other anthropologists who have worked with the Yanomami. The resulting controversy was to lead the American Anthropological Association (AAA) to host an emergency open forum at their 2000 meeting in San Francisco, and conduct an inquiry, establishing two task forces to investigate the allegations (Borofsky 2005; Sponsel 2010). I am less concerned here with the ensuing debates within the anthropological community, which ranged from polemic about the nature of the anthropological endeavour - "science versus postmodernism, sociobiology versus cultural anthropology, Hobbesian vs. Rousseauean interpretations, and the like" (Sponsel 2010: 1) - to arguments about the ethical and human rights responsibilities of anthropological researchers, from the 1960s until the present day. Rather, I am concerned, perhaps slightly mischievously, to consider how and whether the effects of Chagnon and Neel's research might be considered 'impact', and if so, what this might say about the notion of 'impact' and its relationship to anthropological research.

Accounts of the Darkness in El Dorado controversy centre on two main accusations against Neel and Chagnon. Neel was engaged in genetic research, exploring the relationship between genetics, ecology and evolution. The Yanomami represented for Neel an opportunity to view genetic adaptation among a group who were "living under the conditions that characterized most of human evolution" (ASHG 2002: 3). He put together a team of researchers, including Chagnon, who would collect linguistic and physiological data, samples of various bodily fluids and - Chagnon's particular task - genealogical data. Their arrival coincided with the outbreak of a measles epidemic that claimed a number of lives - perhaps hundreds - among the Yanomami. Tierney's contention was that Neel and his team at best failed to adequately safeguard the Yanomami against the disease, and at worst actually caused the epidemic, either accidentally or as part of an experiment on genetic responses to disease. 
Chagnon's primary role in the project was to collect genealogical data in the context of which the human samples could be analysed (Borofsky 2005: 42). Thus rather than the more common ethnographic method of long-term residence in a single settlement or among a single group, Chagnon favoured a more mobile research strategy, moving rapidly from group to group to collect data. This was partly determined by the pace of Neel's sample-collecting project, but also the content of the data he required. Genealogical information among the Yanomami was subject to strict taboos, which meant Chagnon's informants were evasive, dissimulating and often hostile when he tried to ask about kin relations. To get around this he travelled around, seeking out rivals or enemies who would be less concerned about breaking taboos:

"I began taking advantage of local arguments and animosities in selecting my informants $[\ldots]$ I began traveling to other villages to check the genealogies, picking villages that were on strained terms with the people about whom I wanted information" (Chagnon 1968: 12).

It was this somewhat opportunistic attitude towards conflict among the Yanomami that framed the second of Tierney's main accusations. Namely, that Chagnon exaggerated the extent to which the Yanomami are inherently war-like, aggressive 'Fierce People', as the subtitle of his most famous Yanomami ethnography suggests. Tierney, along with other commentators - some of whom were themselves experts on, and had worked with the Yanomami - claimed that on the contrary, the Yanomami were (and are) a relatively peaceful group, but that Chagnon had dwelt on, exploited and even exacerbated conflict and warfare among them, on some occasions actually commissioning violence to be filmed. This was not merely a matter of representation. The depiction of the Yanomami as a fierce people played into the hands of Brazilian gold miners, contributing to arguments against the establishment of a Yanomami land reserve on the grounds that their propensity to violence meant that they could not be trusted (Borofsky 2005: 62). This broader political economy articulated with a smaller-scale political economy to which, argued Tierney, Chagnon played his part. The claim was that in distributing steel goods, including machetes, in return for access and information - including the taboo kinship data - he fuelled a pre-existing demand for steel goods that in turn contributed to a political economy of status, leadership and violence. In this matter, Tierney followed R. Brian Ferguson whose Yanomami Warfare: A Political History (1995) argued that far from being the isolated and pristine tribe presented by Chagnon (see Borofsky 2005: 5), the Yanomami had been in direct or indirect contact with non-indigenous people for centuries and through them had access to iron and steel goods, which were highly prized. Chagnon's arrival and strange requests for genealogical data skewed this economy, placing Chagnon himself at its centre: 
“... his quest for the taboo names of dead ancestors, his being the source of Western goods that every village wanted to monopolize - created a very different and "un-Yanomami" context for his behaviour. Chagnon thus became something of a wild card on the local political scene" (Ferguson 1995: 288).

"Within three months of Chagnon's sole arrival on the scene, three different wars had broken out, all between groups who had been at peace for some time and all of whom wanted a claim on Chagnon's steel goods. 'Chagnon becomes an active political agent in the Yanomami area,' says Brian Ferguson [in a telephone interview conducted by Tierney]. 'He's very much involved in the fighting and the wars. Chagnon becomes a central figure in determining battles over trade goods and machetes. His presence, with a shotgun and a canoe with an outboard motor, involves him in war parties and factionalism. What side he takes makes a big difference'" (Tierney 2000: 30).

The case presented by Tierney, therefore, focuses on two impacts generated by the Neel-Chagnon research project - the measles epidemic and the escalation of warfare. Clearly these are negative impacts, and the strenuousness with which Neel's colleagues (Neel himself died shortly before the Tierney publication) and Chagnon have rejected Tierney's arguments, suggest they would never themselves claim them as impacts. Indeed, the accusation that Neel caused the measles epidemic has been shown to be false, though the debate about Chagnon's influence on Yanomami society rumbles on.

I introduce this admittedly rather extreme first example to highlight two features of the REF impact process. First, its dependence on a retrospective re-narration of past events. In effect, Tierney's account of the Yanomami research is a narrative that resembles an impact case study, presenting evidence in order to demonstrate lines of causality - chains of evidence - that link research to the specific impacts that are claimed in Darkness in El Dorado. This is an obverse - perhaps perverse - case study, in that it refers to negative impacts that are denied by the researchers themselves, but the principle is the same: a retrospective back-tracing from a set of outcomes/impacts to their apparent causes, in order to establish the researcher at the centre of the impact causality. That it took an AAA commission to investigate and eventually exonerate Neel and Chagnon from the charges of causing the measles epidemic should ring alarm bells for the REF panels, especially as the claims that Chagnon encouraged Yanomami violence continue. Just how easy will it be to make judgements about chains of evidence in REF case studies, and upon what will those judgements be made?

The second feature of the REF impact assessment to which I wish to draw attention is that in many cases our understanding of 'positive' and 'negative' 
impact will be contextual. One person's 'positive' is another's 'negative'. This appears to be unacknowledged in the ways the impact case studies are framed by the REF. Their focus is more on the processes by which impact can be demonstrated than on what kinds of impact we prefer. REF panels - those who adjudicate the quality of impact case studies - are asked to exercise their expert judgement when making more qualitative evaluations, but here the REF presumes a homogeneity of opinion as to the panels' views as to what is good, bad or indifferent impact. I emphasise once again that in the case of the Yanomami research, nobody would wish to claim positive impact, though there may be contexts in which the final outcome, or impact, might be said to justify an initially more problematic impact. For example, if our understanding of immunisation or epidemiology were significantly improved then might this justify the impacts of which Neel and Chagnon were initially accused? It is not clear, though, the extent to which the expert panels are expected to make these kinds of judgements, and effectively reconvene as retrospective research ethics committees. Furthermore, as Borofsky's (2005) account of the whole Darkness in El Dorado controversy demonstrates, the anthropological community - at least in the USA - is profoundly divided. It is difficult to see how a REF panel, if it were representative of the breadth of anthropological scholarship, could make a simple single judgement about Chagnon's Yanomami impact. The controversy and division has been recently re-fuelled, following Chagnon's 2013 publication of his autobiography: Noble Savages: My Life Among Two Dangerous Tribes - the Yanomamo and the Anthropologists, his election to the US National Academy of Sciences (NAS) and the subsequent resignation of Chicago Professor Marshall Sahlins, in protest.

\section{HUMAN TERRAIN}

Sahlins made two complaints in his resignation letter to NAS. First, at the election of Chagnon who, he says "has done serious harm to the indigenous communities among whom he did research" (Golden 2013). Second, at the NAS's involvement in joint research collaborations with the US military, to improve their "mission effectiveness" (Sahlins 2013). The move was part of a broader process that has been described as the "military invasion of anthropology" (Ferguson 2013), whereby ethnographic expertise has been called upon to provide military commanders with knowledge of local populations in combat arenas. The best known of these initiatives is the so-called Human Terrain System (HTS).

The first proposal for an Office for Operational Cultural Knowledge was made by Montgomery McFate and Andrea Jackson (2005), who saw an understanding of the local populations - 'human terrain' - within combat arenas as "critical to defeating [the] adversary" (2005: 20). An absence of local 
cultural knowledge, they argued, had hindered counterinsurgency in Iraq and Afghanistan, and McFate, who had worked with Irish Republican Army networks for her PhD research, proposed an ethnographic solution. The Office - which came into existence as the Human Terrain System - would, among other things:

"Provide on-the-ground ethnographic research (interviews and participant observation) in all areas of strategic importance (such as Eastern Europe, the Maghreb, Sub-Sahara Africa, the Middle East, Southwest Asia, Central Asia, and Southeast Asia) to support development of training, education, wargames, Red Teams, planning, and concepts" (McFate and Jackson 2005: 20).

Most controversially, HTS involves embedding trained anthropologists within combat groups to "inform [...] decision making at the tactical, operational and strategic levels" (HTS n.d., cited in Forte 2011: 150). Although supporters of HTS suggest that the information provided by HTS is aimed at reducing the need for 'kinetic' (i.e. violent) interventions in Iraq, Afghanistan and elsewhere, military sources suggest that cultural awareness and ethnographic knowledge should be integrated into all areas of military decision-making (Ferguson 2013: 89).

As with the Darkness in El Dorado controversy, the AAA was quick to respond to the establishment of HTS. In 2005 it established a commission to examine the implications of anthropologists' engagement with the US military, and in 2007 it issued an executive statement on HTS, which raised five concerns about the HTS programme, ultimately expressing its disapproval of HTS on the grounds that anthropologists within HTT (Human Terrain Teams) would breach the AAA's ethical guidelines. First, anthropologists with HTT would not necessarily be able to identify themselves as anthropologists, thereby breaching guidelines on disclosure. Second, because of their responsibility to the military, they may be required to engage in activities that cause harm to their informants. Third, voluntary informed consent would be difficult to ensure in the military context. Fourth, they may provide information to the military that is used to cause harm to their informants or other groups. Fifth, because HTS specifically identifies anthropologists as its agents, their identification with the military potentially threatens the safety of other anthropologists working in conflict situations - or indeed elsewhere (AAA 2007).

Prominent US anthropologists established the Network of Concerned Anthropologists (NCA) to draw attention to the problems with HTS, and in 2009 a second AAA Commission on Anthropology's Engagement with United States Security and Intelligence Communities (CAEUSSIC) issued its final report, which effectively condemned HTS as not only unethical but also 
superficial, inciting superficial “'windshield ethnography' that falls short of professional standards” (Albro and Gusterson 2012):

"When ethnographic investigation is determined by military missions, not subject to external review, where data collection occurs in the context of war, integrated into the goals of counterinsurgency, and in a potentially coercive environment - all characteristic factors of the HTS concept and its application - it can no longer be considered a legitimate professional exercise of anthropology" (CEAUSSIC 2009: 3).

My question here is whether, despite the criticism, it might be possible to present an initiative such as HTS as an example of impact. Although the CEAUSSIC report was sceptical as to whether HTS had reduced conflict or the need for 'kinetic' intervention (2009: 55), defenders of the programme have argued that it does. Military commanders have estimated that combat operations can be reduced by up to $60 \%$ with the inclusion of embedded anthropologists, who focus troops' attention on "improving security, health care and education for the population" (Rohde 2007). The example of anthropologists working with troops in Operation Khyber (2007) is often cited as a success story. The anthropologist working with $73^{\text {rd }}$ Cavalry Division during the operation observed a particular problem in one of the villages they encountered, with widows living in poverty. This put pressure on their sons, she argued, to enlist in the relatively well-paid Taliban insurgency. Her solution was to propose a job-training programme for the widows, capitalising on the local textile trade, which would give them autonomy and free up their sons to seek employment elsewhere (Peterson 2007, Rohde 2007). As defenders of HTS have argued:

"In fact, officers have said that 'the goal of HTS is the same as that of the American Anthropological Association (AAA) code of ethics: 'do no harm' - while they add the qualification 'or at least help the military to do less harm"” (Forte 2011: 151 - quoting HTS FAQ).

If this could be shown to have worked, might one envisage a strong impact case study being narrated about Operation Khyber? Indeed, more dramatically, might an account of research leading to the killing of insurgents be considered impact? Clearly, given the CEAUSSIC conclusions, there are questions about the quality of the research leading to impact - which is one of the REF's criteria - and the expert panel would need to suspend ethical considerations. As with the possible case of an impact story around immunisation and the Yanomami, however, it might be argued that the ends justify the means. In any case, it is not clear to what extent REF expert panels are expected to convene as 
an impromptu (and retrospective) ethics committee. REF case studies are asked to demonstrate the high quality of the research outputs, rather than the ethical probity of their research. As seen in the Chagnon case, unpicking the ethical implications of the research was largely possible because of the author's own striking reflexivity about research process. For most research, this insight into the terms in which research is conducted is simply not available. This poses problems for the REF project, which are exacerbated by the time-frame of REF. Panels are asked to consider the impact of research conducted as long ago as 1993. This is before the consolidation of current research ethics regimes, suggesting further difficulties with the retrospection of the REF impact process.

An impact case study for Operation Khyber would not require the retrospective rewriting of many REF case studies, as the impact was planned and purposive. It is also very much in keeping with the overall focus of impact, which is to emphasise the need for research that serves the national interest. In the UK, the wars in Iraq and Afghanistan are themselves justified on this basis - that through its interventions, the military is directly reducing the risk of serious terrorist acts taking place in the UK itself. Indeed, ESRC - together with the UK's Foreign and Commonwealth Office (FCO) - attempted to launch its own controversial counter-terrorist research programme, this time aimed not at direct intervention for counterinsurgency, but at countering 'radicalisation' (Spencer 2010). This was to be achieved, according to the first draft of the call for applications, in 2006, through a series of in-country case studies in the Gulf, Central Asia and Southeast Asia, that would answer specific questions - in effect, a counter-terrorism intelligence 'wish list' - about the levels and causes of radicalisation. Jonathan Spencer sums up the rather perplexed response from academics invited to contribute to the programme:

"As one distinguished historian of the Middle East put it, 'Names, organisational details, social base, contacts [...] you feel they would have asked for map co-ordinates if they could get away with it"” (Spencer 2010: S292).

The initial version of the programme was quickly withdrawn when it was pointed out that - like the HTS in USA - it could seriously endanger scholars, many of them anthropologists, who worked in the regions and nations targeted for case study. Spencer, together with John Sidel, a political scientist, attempted to work with the ESRC to develop a less problematic proposal, but when the explicit links to the UK's counter-terrorism policy were maintained in the final call, they resigned and the call went ahead, to further academic protest.

It would seem, then, that programmes such as HTS and the ESRC/FCO 'New Security Challenges: Radicalisation and Violence' - as the programme was finally named - are tied to the expectation of impact that directly serves policy 
interests. Indeed they are commissioned explicitly with this kind of impact in mind. Interestingly, perhaps thankfully, the UK programme appears to have provided little in the way of direct policy input to FCO counter-terrorist intelligence. According to the end of programme evaluation, published on the ESRC website:

"The FCO hoped for research that would impact directly on policy decisions and were disappointed in the outcome. For the Programme Director, any explanation of the limited short-term impact should acknowledge that many investigators took positions at odds with those held by the Government" (Tilley, Bouhana and Braithwaite n.d.: 2).

It seems, as Spencer suggests (Spencer 2010: S294), that the academic community thwarted the more instrumentalised impact agendas of the programme. Might we expect, then, that a committee of REF experts would do the same, and refuse to acknowledge impact that goes against disciplinary ethics or politics, even though it would seem to chime with broader Governmental policy aims? In the event, both HTS and New Security Challenges research would fall short of the criteria - the former on the grounds of quality of underpinning research, the latter on the grounds of the policy impact of the research. However, this need not necessarily have been the case, and so potentially places the REF committees in a difficult position. Once again, implicit judgements about what constitutes 'good' and 'bad' impact seem to underpin the research commissioning and evaluation process.

\section{FIELDS OF WHEAT, HILLS OF BLOOD}

In 1996, Anastasia Karakasidou submitted a final version of her manuscript for a monograph called Fields of Wheat, Hills of Blood (Karakasidou 1997) to Cambridge University Press for publication. The book was based on fieldwork in Greek Macedonia and although not formally contracted to Cambridge, had been accepted by the editors of their anthropology monographs series, who had worked with Karakasidou and the manuscript reviewers on the volume. The book examined nationalism and ethnicity in Greek Macedonia, with a particular focus on the processes of national identity-formation, or 'Greekification' of the Macedonian people. Most controversially, the book identified a small minority living within Greek Macedonia who spoke a Slavic language and considered themselves to be Macedonia Slavs, rather than Greeks. This was controversial, as it contradicted the Greek state nationalist ideology to which "Macedonia is one and only and it is Greek" (Clogg 1996).

In the complex anthropology of post-Yugoslav Southern Europe/the Balkans, Karakasidou's observations were not particularly startling, where the 
strongest ethnographic work at the time was identifying a plethora of regional-ethnic-national anomalies to the established - or perhaps one should say establishing - geopolitics of the post-Yugoslav-wars era. However, they had been met with aggression by Greek nationalists in both USA and Greece, who issued death and rape threats to Karakasidou, as well as publishing her fieldwork address and car number-plate, following earlier publications which made the same observations. These threats extended to Michael Herzfeld, a supervisor of Karakasidou's post-doctoral research at Harvard, and editor of the Cambridge series.

With these controversies and threats, Cambridge University Press consulted its staff in Greece, and the British authorities in both Greece and UK, concluding that the publication of Fields of Wheat, Hills of Blood could endanger the lives of Press staff in Greece and elsewhere. As a result, they decided to cancel its publication. There was an immediate outcry in the academic community. Herzfeld and his co-editor Stephen Gudeman resigned from the series on the grounds that the decision constituted censorship - a serious infringement to academic freedom. They argued that the threats to Press staff were exaggerated and - in echoes of the Darkness in El Dorado controversy - perpetuated stereotypes of Greeks as dangerous, volatile and violent. Correspondence on the email list of the AAA's Society for the Anthropology of Europe, H-SAE, suggested that it was not primarily safety that concerned the Press, but economic interests. Greece was - and is - an important market for their lucrative 'English as a Foreign Language' (EFL) publications and franchise. Whilst a violent reaction was unlikely, it was argued, a boycott of Cambridge University Press EFL products was a possible outcome, and one which the Press could not risk.

On the face of it, this example is less to do with impact than the politics of academic production, yet it also demonstrates that the relationship between academic and state politics is closer than definitions of 'impact' might suggest. The case does demonstrate potential impact in a number of spheres: first, the impact of generating violent threats or action; and second, the impact of influencing the market for teaching and research publications. These might both be seen as 'bad' impacts. A third impact, however, could be seen as 'bad' or 'good', depending on one's political viewpoint. This is the impact inherent in generating political debate about Macedonian minorities. The social science 'panel C' guidelines specify that impact may include research that enables "challenge to conventional wisdom" (REF 2012: 70). There seems to be broad expectation, though, that such research, whilst generating "critique or dissent" (2012: 68) will lead to wisdoms or approaches being "questioned or modified" (2012: 68). In the case of Karakasidou's work, if anything, the conventional wisdoms were consolidated or further entrenched by the research, rather than being questioned or modified. This begs the question as to whether REF and the overall focus on impact discourages work with a genuinely critical edge, 
favouring instead work in which impact is planned for a likely receptive audience. In a context in which research is commissioned increasingly on the basis of planned and likely impact, are projects which challenge received wisdom but do not promise to overthrow it less likely to be funded?

Projects that promise impact whilst effectively knocking on already-open doors will tend to be inherently conservative, reinforcing assumptions rather than genuinely challenging them. This is problematic for a discipline such as anthropology, which has effectively written itself a political remit of identifying and representing the viewpoints and rights of minority and indigenous peoples, not only against the state but also against the interests of global capital.

\section{CONCLUSION}

This returns us to the relationship between contemporary research agendas and the ethical programme of neoliberalism. As Binkley argues (2009a, $2009 b$ ), successful entrepreneurship within a neoliberal frame requires particular modes of self-making - or self-narrating - to generate the appropriately successful 'rich dad' account of past, present and future. In the context of the retrospective REF impact process, and the prospective RCUK requirement for impact planning, this requires researchers to recast the past and anticipate the future as points on a purposive and successful linear teleology - the development of 'impact dad'.

As we have seen, however, assessment about what constitutes 'good' and 'bad' impact can be complex and contentious. They bring to bear judgements about ethical practice, but also, perhaps more significantly - and as Spencer argued over the 'New Security Challenges' controversy - political judgements. These may involve academic politics, as with Darkness in El Dorado, about whether the pursuit of science should be the central agenda for anthropology, trumping issues of representation. They may equally involve state politics, as with both the Human Terrain and Fields of Wheat controversies.

I have presented three examples of what has been called 'bad' impact anthropologists behaving 'badly'. However they are examples that range from the indefensible (causing a measles epidemic), to the debateable (reducing conflict through the military embedding of anthropologists), to what most anthropologists would regard as the righteous (countering nationalist rhetoric by identifying minorities). In each case, though, there are positions from which the impact might either be defended or criticised, depending on academic or state political opinion. The successful narrative of a successful 'impact dad', then, is not unequivocal. The more so when an anthropologist behaving badly criticises neoliberalism itself.

I return to the - albeit hypothetical - example of David Graeber and the potential impact of activist research engaged and embedded within 
contemporary counter-capitalist politics. Graeber is just one of a number of anthropologists currently working in such contexts, with not only intellectual but also political agendas informing their work. Given the explicit links made in RCUK literature between impact and the pursuit of the UK's economic interests, it seems unlikely that impact of this type would be well received. The problem is that impact, as conceived by REF and RCUK, appears as apolitical, but like broader neoliberal agendas has a politics that is only manifest when directly challenged. Such challenge is likely to meet with opposition, as with the Greek response to Karakasidou's research, but perhaps that demonstrates it is 'better' impact than that which pushes on the already-open door. Perhaps anthropologists have better impact when they are behaving badly.

\section{REFERENCES}

AAA (American Anthropological Association), 2007, American Anthropological Association Executive Board Statement on the Human Terrain System Project, available at <http://www.aaanet. org/about/policies/statements/human-terrain-system-statement.cfm > (last access 2014, May).

Albro, Rob, and Hugh GUSTERSON, 2012, "Commentary: 'Do No Harm'”, Defense News, April 25, available at <http://www.defensenews.com/article/20120425/C4ISR02/3042 50001/Commentary-8216-Do-No-Harm-8217-> (last access 2014, May).

ASHG (American Society of Human Genetics), 2002, "Response to allegations against James V. Neel in Darkness in El Dorado, by Patrick Tierney", American Journal of Human Genetics, 70: 1-10.

BARTH, Fredrik, 2002, "An anthropology of knowledge”, Current Anthropology, 43 (1): 1-18. BECK, Ulrich, 1992, Risk Society: Towards a New Modernity. London, Sage.

BINKLEY, Sam, 2009a, "The work of neoliberal governmentality: temporality and ethical substance in the tale of two dads", Foucault Studies, 6: 60-78.

BINKLEY, Sam, 2009b, "Governmentality, temporality and practice: from the individualization of risk to the 'contradictory movements of the soul'”, Time \& Society, 18 (1): 86-105.

BOROFSKY, Robert, 2005, Yanomami: The Fierce Controversy and What We Can Learn from It. Berkeley, University of California Press.

CEAUSSIC (Commission on the Engagement of Anthropology with the US Security and Intelligence Communities), 2009, Final Report on The Army's Human Terrain System Proof of Concept Program, available at <http://www.aaanet.org/cmtes/commissions/CEAUSSIC/upload/CEAUSSIC_HTS_Final_Report.pdf> (last access 2014, May).

CHAGNON, Napoleon, 1968, Yanomamo: The Fierce People. New York, Holt, Rinehart \& Winston.

CLOGG, Richard, 1996, "Press clanger", Times Higher Education, April 1. 
FERGUSON, R. Brian, 1995, Yanomami Warfare: A Political History. Santa Fe, School of American Research Press.

FERGUSON, R. Brian, 2013, "Full spectrum: the military invasion of anthropology", in Neil L. Whitehead and Sverker Finnstrom (eds.), Virtual War and Magical Death: Technologies and Imaginaries for Terror and Killing. Durham, NC, Duke University Press.

FORTE, Max C., 2011 , "The Human Terrain System and anthropology: a review of ongoing public debates”, American Anthropologist, 113 (1): 149-153.

GOLDEN, Serena, 2013, "A protest resignation", Inside Higher Ed, February 25, available at $<$ http://www.insidehighered.com/news/2013/02/25/prominent-anthropologist-resignsprotest-national-academy-sciences $>$ (last access 2014, May).

GRAEBER, David, 2007, Revolution in Reverse (Or, on the Conflict between Political Ontologies of Violence and Political Ontologies of the Imagination), available at <http://theanarchistlibrary. org/library/david-graeber-revolution-in-reverse > (last access 2014, May).

HABERMAS, Jürgen, 1987, The Philosophical Discourse of Modernity. Cambridge, MA, The MIT Press.

KARAKASIDOU, Anastasia, 1997, Fields of Wheat, Hills of Blood: Passages to Nationhood in Greek Macedonia, 1870-1990. Chicago, The University of Chicago Press.

KIYOSAKI, Robert T., 2002, Rich Dad Poor Dad: What the Rich Teach Their Kids about Money that the Poor and Middle Class Do Not. London, Warner.

MAECKELBergh, Marianne, 2009, The Will of the Many: How the Alterglobalization Movement Is Changing the Face of Democracy. London, Pluto.

MAECKELBERGH, Marianne, 2012, "Horizontal democracy now: from alterglobalization to occupation" Interface: A Journal for and about Social Movements, 4 (1): 207-234.

McFATE, Montgomery, and Andrea JACKSON, 2005, “An organizational solution for DOD's cultural knowledge needs", Military Review, July-August: 18-21.

MILlER, Daniel, 1994, Modernity: An Ethnographic Approach. Oxford, Berg.

NCCPE (National Co-Ordinating Centre for Public Engagement), 2011, Update on Public Engagement and the REF. Bristol, NCCPE.

OKELY, Judith, 2012, Anthropological Practice: Fieldwork and the Ethnographic Method. London, Berg.

OZGA, Jenny, 1998, “The entrepreneurial researcher: re-formations of identity in the research marketplace”, International Studies in Sociology of Education, 8 (2): 143-153.

PETERSON, Scott, 2007, "US Army's strategy in Afghanistan: better anthropology”, Christian Science Monitor, September 7.

POWER, Michael, 1997, Audit Society: Rituals of Verification. Oxford, Oxford University Press.

REF (Research Excellence Framework), 2011 , Assessment Framework and Guidance on Submissions. Bristol, REF.

REF (Research Excellence Framework), 2012, Main Panel C Criteria. Bristol, REF.

ROHDE, David, 2007, "Army enlists anthropology in war zones", New York Times, October 5.

SAHLINS, Marshall, 2013, "The National Academy of Sciences: goodbye to all that", Anthropology Today, 29 (2): 1-2.

SHORE, Cris, 2008, "Audit culture and illiberal governance: universities and the politics of accountability", Anthropological Theory, 8 (3): 278-298.

SPENCER, Jonathan, 2010, "The perils of engagement: a space for anthropology in the age of security?", Current Anthropology, 51 (S2: Engaged Anthropology: Diversity and Dilemmas): S289-S299. 
SPONSEL, Leslie, 2010, "Is there any light in the Darkness in El Dorado controversy a decade later?", unpublished manuscript, available at < anthroniche.com/darkness_documents/061 1.pdf> (last accessed 2014, May).

STRATHERn, Marilyn (ed.), 2000, Audit Cultures: Anthropological Studies in Accountability, Ethics and the Academy. London, Routledge.

TIERNEY, Patrick, 2000, Darkness in El Dorado: How Scientists and Journalists Devastated the Amazon. New York, Norton.

TILLEY, Nick, Naomi BOUHANA, and Alex BRAITHWAITE, n.d., Evaluation of the ESRC/ FCO/AHRC New Security Challenges: Radicalisation and Violence, a Critical Assessment Initiative, available at <http://www.esrc.ac.uk/_images/EC_Executive_Summary_NCSRV_ tcm8-22040.pdf $>$ (last access 2014, May). 